\title{
Narativna medicina

\author{
Pokušaj rekonstrukcije i zadobivanja identiteta putem \\ osobnog narativa
}

Darija Rupčić ${ }^{*}$

darijarupcic@gmail.com https://doi.org/10.31192/np.16.3.2

UDK: 616-01:316

613:316

Izvorni znanstveni rad / Original scientific paper

Primljeno: 23. lipnja 2018.

Prihvaćeno: 6. rujna 2018.

Nakana je rada istaknuti i promišljati o razvijanju jedne rasute manjinske tradicije koja razmatra značaj kulturoloških utjecaja na zdravlje i bolesti. Naglasit će se zamršena, složena i suptilna veza bolesti i kulture. Stavljajući naglasak na narativ ili priču, rad će se kritički osvrnuti na postojeći prevladavajući biomedicinski model bolesti i sagledati mogućnost uvođenja i proširivanja postojećeg modela biokulturnim modelom bolesti. U tom se kontekstu javila i potreba valoriziranja osobnih narativa iskustva bolesti u medicini. Tako se razvila i narativna medicina koja pretpostavlja da puko znanstveno znanje i klinička medicinska praksa nisu dostatne u okolnostima pacijentove osobne borbe s bolesti, te prepoznaje, upija i reinterpretira njegovo iskustvo. Očekivani doprinos ovoga rada ići će u smjeru mogućnosti teorijskog i praktičkog utemeljenja i uporišta za takva promišljanja, te pokušaj pluriperspektivnog pristupa zdravlju i bolesti. Ključne riječi: bolest, zdravlje, biokulturna paradigma, narativna medicina, metafore zdravlja i bolesti, narativni identitet, model objašnjavanja bolesti.

\footnotetext{
* Dr. sc. Darija Rupčić, znanstvena suradnica, poslijedoktorandica, Filozofski fakultet, Sveučilište J. J. Strossmayer u Osijeku, L. Jägera 9, HR-31000 Osijek.
} 


\section{Uvod}

»Isplači se jednom jako, ako suze žele same doći. Tada zaustavi tugu (...) nađi način da budeš netko drugi, neki drugi ti - sposoban za život.« ${ }^{1}$ Tim je riječima Reynolds Price prvi puta želio ispričati priču kako ga je bolest (rak leđne moždine, otkriven 1984. godine), izmijenila i nije više mogao biti onaj isti. Bez samosažalijevanja htio je istaknuti što je postalo njegova najveća životna borba da izdrži, odoli i oporavi se od užasne nesreće i boli koja ga je zadesila. Opisujući bolove, operacije kroz koje je prošao, ovisnost o lijekovima protiv bolova koje je uzimao, poneke smiješne, komične situacije pokušaja oporavka, borbu s oduzetošću donjeg dijela tijela, snagu neprekidnih religijskih vizija koje su mu nadolazile, nenadano otkriće pomoći koju su mu pružale hipnoza i biofeedback, te nenadan povratak nove snage i moći koje je kao pisac zadobio u novom aktivnom životu, isticao je da je trebalo prihvatiti bolest koja mu je došla i prihvatiti promjenu koju je donijela. Kroz osobni je narativ nastojao zadobiti svoj drugi, novi identitet.

S onu stranu pojedinačne, osobne, subjektivne boli i smrtne bolesti, na površinu je izašla snaga i želja da održi interakciju i veze s dragim ljudima u svojem životu, unatoč bolesti koja ih je kidala i mijenjala. Izražavao je svoju zahvalnost prema njima i isticao istovremeno i zastrašujuću i zadivljujuću snagu Božje milosti i prisutnosti u svojem životu. Njegovo je djelo puno više nego samo portret hrabre osobe koja se borila sa strašnim iskušenjima i patnjom. Ono nam nudi iskreni uvid, realistično ohrabrenje i inspiraciju svima koji se nalaze u teškoj borbi za vlastiti život. Na taj nam način osobni narativ pruža dublju realnost i mogućnost ponovnog oblikovanja tumačenja onoga što bolest jest i što čini za ljudski život, te nudi mogućnost da putem iznošenja i proživljavanja osobnog narativa, onaj koji pati nanovo zadobije svoj identitet te prihvati svoju bolest. U radu će se stoga, nastojati istaknuti upravo važnost osobnog narativa, ali i narativnog znanja koje, iako pomalo zaboravljeno u suvremenoj medicini, ponovno zadobiva svoje značenje i mjesto u nastojanjima i pokušajima shvaćanja i ovladavanja bolešću i osobnim iskustvom koje ona nosi.

Suvremeno je doba obilježeno krizom znanstveno-tehničke racionalne paradigme koja se nameće kao jedini pretendent nositelja apsolutne istine. Ova je kriza zahvatila i područje dominantno prisutnog i znanstveno utemeljenog biomedicinskog modela koji, s jedne strane raste enormnom brzinom, dok $\mathrm{s}$ druge strane već nekoliko desetljeća proživljava svojevrsnu krizu. ${ }^{2}$ Spomenuti model u definiranju bolesti polazi od premise da je bolest predmet, a tijelo promatra u metaforama mehaničkog stroja. Iako je taj model donio napredak $\mathrm{i}$ iskorijenio mnoge bolesti, otvara nam i alternativan put k novom i još uvijek

${ }^{1}$ R. PRICE, A Whole New Life. An Illness and a Healing, New York, Scribner Classics, 1994, 183.

${ }^{2}$ Više o krizi biomedicinske paradigme i modela suvremene medicine u: J. Le FANU, The Rise and Fall of Modern Medicine, New York, Carrol \& Graf Publishers, 2000, 216, 239-240. 
neizvjesnom shvaćanju bolesti kao promjenjivog procesa koji nastaje prožimanjem kulture i biologije. ${ }^{3}$

Bolest je stoga, promatrana kroz biokulturnu paradigmu, zagonetna, neposlušna i subjektivna, za razliku od biomedicinskog shvaćanja bolesti kao kvara stroja. ${ }^{4}$ Upravo je osjetljiva ravnoteža između bolesti i kulture ono što konstituira neuhvatljivu istinu bolesti i postmoderno shvaćanje bolesti kao biokulturne pojave u biokulturnom modelu. Bolesti su uglavnom posljedica zajedničkog djelovanja biologije i kulture, te su tzv. postmoderne bolesti definirane upravo sviješću o tim složenim odnosima kulture i biologije. U tome leži i bit razumijevanja posebnosti tzv. postmodernih bolesti, nasuprot prevladavajućem biomedicinskom shvaćanju. ${ }^{5}$

Postmoderna bolest, zbog svojih zamršenih veza s kulturološki konstruiranim okruženjem, zahtijeva od čovjeka da iznova razmisli o izvorima medicinskog znanja. Društvene, kulturne i osobne dimenzije bolesti moraju se shvatiti drugačijim sredstvima, a jedno je od njih zanemareno, iako korisno, naracija ili priča - način razumijevanja prikladan za situacije koje su previše raznolike i previše nesputane za laboratorijske analize. ${ }^{6}$

Stoga će se u daljnjem izlaganju u radu istaknuti važnost osobnog narativa kao priče kojom bolesnik pokušava iznova izgraditi i zadobiti svoj identitet i slomljenu životnu priču, te istaknuti nov način pristupa i paradigme u suvremenoj medicini koji nastoji sagledati osobni narativ u kliničkoj praksi kao bogati izvor informacija o uzrocima i tijeku bolesti. Ono što je važno napomenuti da kroz osobni narativ medicinski stručnjaci nastoje tretirati pacijenta kao osobu s individualnom, osobnom pričom, a ne svoje znanje temeljiti isključivo na simptomima i kliničkim dokazima.

\section{Novi vid i novi model razumijevanja bolesti - prožimanje biologije i kulture}

Ističući dijadu biologije i kulture, Morris naglašava da se tijekom druge polovice dvadesetog stoljeća pojavio nov oblik razumijevanja bolesti koji je doveo u pitanje različita uvjerenja koja leže u osnovi prevladavajućeg biomedicinskog modela. ${ }^{7}$ Ipak, zapadna je medicina više od jednog stoljeća radila na usavršava-

\footnotetext{
${ }^{3}$ Usp. D. RUPČIĆ, Bolest u procjepu biologije i kulture. Postmoderno shvaćanje bolesti kao biokulturne pojave, Filozofska istraživanja, 36 (2016) 3, 421-438, 421.

${ }^{4}$ Usp. D. B. MORIS [D. B. Morris], Bolest $i$ kultura u postmodernom dobu, Beograd, Imago Clio, 2008, 19.

${ }^{5}$ Usp. isto, 9.

${ }^{6}$ Usp. Rupčić, Bolest u procjepu biologije i kulture..., 422.

7 Više o novom Engelovom biopsihosocijalnom modelu vidi u: Moris, Bolest $i$ kultura..., 93; B. LEWIS, Provocation. Call This a Medical Humanities? From Medical Humanities to Biocultures, Atrium, 7 (2009) 9-10; B. LEWIS, What is Biocultures?, Literatures Arts and Medicine Blog,
} 
nju i svesrdnom podupiranju dominantnog utemeljenog diskursa zasnovanog na sagledavanju bolesti kao proizvoda bioloških i kemijskih mehanizama u tijelu. Tradicionalni biomedicinski model, usprkos otporu, propustima i nekim očiglednim manama i dalje ostaje vladajuća paradigma suvremene zapadnjačke medicine.

Novo shvaćanje kulture snažno oblikuje i ozbiljno utječe i na naše shvaćanje bolesti tako da su one, iako uvijek biološke, postale dijelom i kulturni artefakti i konstrukti na isti način na koji je to i medicina, budući da djeluju putem diskursa koji društvenu moć raspoređuju preko institucija i pojedinaca. ${ }^{8}$

Morris izriče uvjerenje da bolest ne ovisi samo o biološkim mehanizmima, već i o prožimanju biologije i kulture, te naglašava važnu ulogu koju prilikom definiranja bolesti ima naracija ili priča. Takva narativna prožimanja nisu mogla svesti bolest na mehanicistički model, te su ukazala na pojavu teorije sustava kao dominantne metafore za bolest. Upravo ti novi oblici razumijevanja bolesti određuju specifične i složene načine na koje, mi u postmodernom dobu, nastojimo sebe iznova osmisliti i izgraditi svoj identitet. ${ }^{9}$

Međutim, jedna od glavnih karakteristika postmoderne njezina je neodređenost koja taj pojam čini pogodnim za definiranje razdoblja naglog prijelaza kada postojeće vrijednosti gube svoj prepoznatljiv oblik i značenje. Ono što postmoderno mišljenje može ubrojiti među svoja najveća postignuća jest odbacivanje prosvjetiteljskih teza o univerzalnoj, nepromjenjivoj, uvijek istoj i apsolutnoj ljudskoj naravi. Rušeći mitove o univerzalnoj ljudskoj naravi i nepromjenjivim, univerzalnim vrijednostima i istinama postmoderni su mislitelji isticali kulturne razlike na račun podjednako uvjerljivih dokaza o biološkoj istovjetnosti i postojanosti. ${ }^{10}$

Stoga su ljudska narav, ljudski identitet i s njima u vezi ljudska moralnost, fluidni i ambivalentni jer nema jedinstvenog moralnog koda niti se ljudska narav i moralnost mogu svesti na neki univerzalni moralni kod. Ne može se govoriti o univerzalnoj racionalnoj ljudskoj naravi koja bi bila neovisna o kulturnom kontekstu iz kojeg izranja i u koji uranja. Postmoderni mislitelji ističu da su ljudi bića u potpunosti određena kulturom, a ne isključivo društvena i biološka bića, određena genima i naslijeđem. Kultura je, združena s biologijom, postala glavni određujući čimbenik ljudske naravi.

(2007), http://medhum.med.nyu.edu/blog/?p=34 (20.07.2015); o manifestu biokulture vidi: D. B. MORRIS, Lennard J. DAVIS, Biocultures Manifesto, New Literary History, 38 (2007) 3, 411418; doi: https://doi.org/10.1353/nlh.2007.0046.

${ }^{8}$ Usp. J. C. KUIPERS, 'Medical Discourse' in Antropological Context: Views of Language and Power, Medical Anthroplology Quartely, 3 (1989) 2, 99-123; doi: https://doi.org/10.1525/ maq.1989.3.2.02a00010.

${ }^{9}$ Usp. Moris, Bolest i kultura..., 20.

${ }^{10}$ Usp. isto, 24. 


\section{Promjena medicinskog opažanja i pogleda - rađanje pozitivističke medicine}

U svojem djelu Rađanje klinike. Arheologija medicinskog opažanja, M. Foucault zorno ističe da je riječ o medicinskom opažanju, o medicinskom pogledu i njegovoj promjeni tijekom kraja 18. i početkom 19. st. naovamo. Što on zapravo tvrdi? Spominjući dva primjera objašnjavanja bolesti opisuje razliku u jeziku, govoru i načinu objašnjavanja tijeka, uzroka i načina liječenja bolesti. Jedna je priča s kraja 18. st. o tome kako liječiti histeričnu ženu, gdje se koristi jezik fantazme, bez opažajne podrške. Druga je priča nastala nešto manje od 100 godina kasnije o tome kako je neki liječnik vidio lezije na mozgu i njegovim opnama. Uočljiva je razlika u načinu izražavanja i govora koji kvalitativnom preciznošću vodi naš pogled i razumijevanje uzroka i tijeka bolesti prema jednom neprestano vidljivom svijetu. Namjera je autora jasna. Otkloniti fantastične, subjektivne oblike razumijevanja i govora i bez njih voditi do očiglednosti, do stvarnog stanja stvari. ${ }^{11}$

Foucault ističe da pozitivistička medicina nije u potpunosti objektivirana, taj prostor gdje liječnik i pacijent komuniciraju nije nestao, nego je premješten $\mathrm{u}$ osobu, u pacijenta, $\mathrm{u}$ one tzv. subjektivne simptome, u subjektivan pacijentov način iznošenja i objašnjavanja koji se kasnije oblikuju u osobni narativ i pacijentovo iskustvo bolesti. Taj pacijentov opis subjektivnih simptoma i doživljaja tegoba za liječnika više ne definira način njegove spoznaje, nego postaje svijet i prostor koji tek treba spoznati. ${ }^{12}$

Oblici bola i tegoba nisu uklonjeni u korist neke neutralne, objektivne spoznaje, nego su, ističe Foucault, premješteni u prostor u kojemu se ukrštaju tijela i pogledi. Ono što se promijenilo su nejasne jezične konfiguracije da bi opis postao jasan i artikuliran, mijenja se odnos onoga koji govori i onoga o čemu se govori. ${ }^{13}$ Jezik se racionalizirao, a s njime i sama medicina, te mnogi u tome prepoznaju i krizu skrbi koja je u suvremenoj medicini i danas prisutna i očita.

Medicinski se jezik pozitivizirao, racionalizirao, artikulirao i objektivirao. Upravo je to vrijeme rađanja klinike i kliničkog iskustva. Moderna medicina, rođena potkraj 18. st., tvrdi Foucault, porijeklo svoje pozitivnosti poistovjećuje s povratkom djelotvornoj skromnosti opaženoga. ${ }^{14}$ Otvaranje, kako kaže Foucault, konkretne individue jeziku racionalnosti, početak je moderne medicine i klinike. Bolesnički krevet postaje poprište istraživanja i znanstvenog diskursa.

Medicina se kao klinička znanost pojavila u uvjetima koji određuju domenu njezinog iskustva i strukturu njezine racionalnosti. Zahvaljujući iskustvu i

\footnotetext{
${ }^{11}$ Usp. M. FUKO, Radanje klinike. Arheologija medicinskog opažanja, s fran. prev. O. Petronić, Novi Sad, Mediterran Publishing, 2009, Predgovor, 9-10.

${ }^{12}$ Usp. isto, 10.

${ }^{13}$ Usp. isto, 11.

${ }^{14}$ Usp. isto, 12.
} 
racionalnosti ona postaje konkretna i ima mogućnost rasvjetljavanja uzroka i tijeka bolesti, te na taj način rađa novo iskustvo bolesti prisutno i dominantno sve do danas u suvremenoj medicini. ${ }^{15}$ Biomedicinsko iskustvo i model bolesti.

U čemu se očituje ta velika promjena koja je medicinu preobrazila i učinila racionalnom i pozitivnom znanosti? Klinička se medicina pojavila kao nova paradigma iskustva koje postaje vidljivo, opazivo i iskazivo, događa se reorganizacija liječenja koja bolest objektivira, te ona postaje glavni fokus medicine. Ta je nova pojava vidljiva u banalnoj promjeni koja je pitanje: »Što Vam je?«, kojim bi u 18. st. počinjao dijalog liječnika i pacijenta, zamijenila pitanjem u kojem zamjećujemo načelo novog diskursa, kako ističe Foucault: »Gdje Vas boli? «16 Događa se lokaliziranje i objektiviranje boli i bolesti, mijenja se odnos onoga koji opisuje, između simptoma koji označavaju bolest i bolesti same. Foucault naglašava da se događa dubinska reorganizacija ne samo medicinskih spoznaja, nego i same mogućnosti diskursa o bolesti.

\section{Medicina koja čeka}

Tijelo je, u medicini 19. stoljeća, tvrdi nadalje Foucault, bilo mjesto podrijetla i razmještanja bolesti, prostor čije je granice, zapremine, površine i putove utvrdio, u skladu s poznatom geografijom, anatomski atlas. Taj je čvrsti poredak $u$ tijelu samo jedan od načina na koji je medicina projicirala bolest $u$ prostor. Potreba da se bolest definira značila je želju da je se podčini, otkloni i učini poznatom. Da bi se spoznala istina o patološkoj činjenici liječnik je morao apstrahirati bolesnika. Paradoksalno, pacijent je u odnosu na ono od čega je bolovao bio samo vanjska činjenica. Medicinsko je iščitavanje trebalo uzeti u obzir bolesnika samo da bi ga stavilo u zagradu. Bolest se izmješta iz bolesnika, pojedinca, iz osobe i smješta se van, u neki imaginaran prostor raspoloživ za eksperimentiranje i »seciranje«. Nije patološko ono što u odnosu na život funkcionira kao protuprirodno, već je to postao bolesnik u odnosu na samu bolest.

No, bolesnik je bolest koja je stekla i poprimila osobne crte, ona je dana sa sjenom i reljefom, modulacijama, preljevima, dubinom, prostorom i kulturom, a posao je liječnika, kada bude opisivao bolest, vratiti i obnoviti one slabosti bolesnika, iste one njegove patnje i žalopojke, iste kretnje, iste stavove, iste riječi. ${ }^{17}$ »Bolnica je, kao i civilizacija, umjetno mjesto u kojem presađena bolest riskira gubitak svoje biti. $^{18}$ Foucault naglašava da na bolesnika otrgnutog od obitelji, bolnica, koju on naziva $\mathrm{i} »$ hramom smrti,$^{19}$ ostavlja neugodan i gorak okus.

\footnotetext{
${ }^{15}$ Usp. isto, 15

${ }^{16}$ Usp. isto, 19.

${ }^{17}$ Usp. isto, 34.

${ }^{18}$ Isto, 35.

${ }^{19}$ Isto, 36.
} 
»Ta naseljena samoća i taj očaj remete, sa zdravim reakcijama organizma, prirodni tijek bolesti; potreban je veoma vješt bolnički liječnik 'da se izbjegne opasnost od lošeg iskustva, čiji su ishod umjetne bolesti, koje on onda mora liječiti u bolnicama. Naime, nijedna bolnička bolest nije čista'. « ${ }^{20}$

Prirodno mjesto bolesti, kako naglašava Foucault, jest prirodno mjesto života - obitelj, toplina spontane njege, svjedočanstvo o privrženosti, zajednička želja za ozdravljenjem, sve se to udružuje da bi se pomoglo prirodi koja se bori protiv bolesti i pustilo bolest da se sama rasprostire u svojoj istini. Foucault ističe upravo način na koji liječnik interpretira i definira bolest, te uočava jasnu distinkciju pojmova bolest i tegobe, kao osobnog viđenja i nošenja s bolešću. Liječnik vidi samo sumnjive, izmijenjene bolesti, čitavu teratologiju patološkog. Onaj koji liječi kod kuće za kratko vrijeme stječe istinsko iskustvo, utemeljeno na prirodnim pojavama svih vrsta bolesti.

Ističući razliku bolničkog umjetnog okruženja i naglašavajući prednosti tzv. kućne medicine, naglašava i njezinu svrhu koja mora biti nužno puna uvažavanja, promatrati bolesnike i pomagati prirodi bez ikakva nasilja i čekati, skromno priznajući da nam nedostaje još mnogo znanja. U posljednje se vrijeme oživljava i stara rasprava o medicini koja djeluje i o medicini koja čeka, koja pomaže prirodi da dovrši prirodno kretanje.

Medicina koja čeka, bez bolničke prinude, ostavlja bolest na njenom mjestu, na kojem se rađa, razvija i ostvaruje svoju bit, mjesto na kojem stiže do svog prirodnog kraja neizbježne smrti - ako je takva njena zakonitost - ili izlječenja, često mogućeg ako ništa ne poremeti njegovu prirodu. Tamo gdje se bolest pojavi smatra se da će ondje i nestati. Ne treba je učvrstiti u neku medicinski pripremljenu domenu, već je treba pustiti da, u pozitivnom smislu riječi, vegetira na svom prvobitnom tlu, žarištu, društvenom prostoru shvaćenom u njegovom najprirodnijem obliku, najprimitivnijem i moralno najsolidnijem, tamo gdje je bolest prepuštena sama sebi. ${ }^{21}$

Klasifikatorska medicina, medicina koja čeka, medicina pojedinačnog opažanja, obiteljske pomoći, kućnog liječenja, koja se polako gubila, ističe Foucault, može naći oslonac samo u nekoj kolektivno kontroliranoj strukturi društva koja pokriva cjelokupan društveni prostor. Tako smo ušli u posve nov i nepoznat oblik institucionalne specijalizacije bolesti i tu se medicina koja čeka polako izgubila. $^{22}$

U kontekstu spomenutoga možemo reći da je od tog doba, od 18. stoljeća, pa sve do pojave suvremene medicine 20. stoljeća, sve vidljivijim i očitijim postala činjenica da je taj biomedicinski model bolesti sve više bivao na kušnji, te su se u nekoliko posljednjih desetljeća u suvremenoj medicini pojavile i drugačije tendencije koje dovode u pitanje spomenuti biomedicinski model bolesti i sve

\footnotetext{
${ }^{20}$ Isto; navodi: D. de NEMOURS, Idees sur les secour a donner, Pariz, 1786, 24-25.

${ }^{21}$ Usp. isto, 36-37.

${ }^{22}$ Usp. isto, 39.
} 
ono što on jest. Arthur W. Frank u svojem djelu The Wounded Storyteller tu činjenicu promjene ističe riječima:

»Postmoderno iskustvo bolesti počinje onda kada bolesni ljudi shvate da njihovo iskustvo obuhvaća mnogo više od onoga što im medicina može reći. Gubitak životne mape i odredišta nisu jednostavno samo medicinski simptomi.« ${ }^{23}$

Što se tiče rastuće distinkcije između znanstvene medicine i umijeća liječenja, čini se važnim istaknuti i Gadamerovo opažanje da znanje o stvarima može biti naučeno, ali umijeće liječenja mora postupno sazrijevati kroz iskustvo i razviti tada svoje vlastito viđenje i moć prosudbe. Ističe da se bolesti sve više promatraju kao predmet, nešto strano, što je nasuprot nama i našim prirodnim impulsima i prijete nam. One bivaju nešto čemu čovjek pruža otpor i ne može ih inkorporirati u svoj život: »Kada se suočimo s bolešću, pokušavamo, tako reći, nadvladati samu prirodu. Ono što nastojimo učiniti jest da nadiđemo bolest i da zadobijemo kontrolu nad njom. ${ }^{24} \mathrm{Za}$ Gadamera nema bolesti bez zdravlja. Oboje pripada onome što doktori trebaju i moraju istražiti. Zdravlja postajemo svjesni uglavnom onda kada iskušavamo ono što nazivamo bolest. Gadamer je tu spoznaju posebno dobro opisao izrazom »skrivenost zdravlja« ili enigmom:

»Otprilike se zna što je bolest. To je onaj 'revolt' ili pobuna koja se događa kada nešto počne loše funkcionirati. Ona je, po načinu svojega pojavljivanja, predmet, nešto što pruža otpor koji treba slomiti. (...) Zdravlje nije nešto što se kao takvo pokazuje u istraživanju, nego nešto što se pokazuje upravo stoga što izmiče našoj pažnji. Zdravlja nismo stalno svjesni, ne brine nas kao bolest. (...) Ono spada u čuda samozaborava. $\aleph^{25}$

\section{Osobni narativ kao restauracija slomljene priče $i$ rekonstrukcija identiteta}

U tumačenju modernog i postmodernog iskustva bolesti Arthur W. Frank govori da su dva iskustva dva različita načina življenja s bolešću.$^{26}$ Ono što je važno uočiti upravo je njihova razlika. U moderni ljudi počinju odlaziti medicinskim profesionalcima koji reinterpretiraju njihove pritužbe i bolove kao simptome, koristeći nepoznat i neshvatljiv specijalizirani jezik, te tako prihvaćaju službenu medicinsko-znanstvenu priču ili paradigmu.

\footnotetext{
${ }^{23}$ A. W. FRANK, The Wounded Storyteller: Body, Illness, and Ethics, Chicago, University of Chicago Press, 1995, 6.

${ }^{24}$ H.-G. GADAMER, The Enigma of Health. The Art of Healing in a Scientific Age, Stanford, Stanford University Press, 1996, 105.

${ }^{25}$ Isto, 96.

${ }^{26}$ Usp. Frank, The Wounded Storyteller..., 5-6.
} 
Postmoderni je način, s druge strane, onaj u kojem pacijenti ponovno zadobivaju moć stvaratelja i naratora vlastitih, jedinstvenih priča. ${ }^{27}$ Međutim, postomoderni svijet površine, hiperrealnog i slika koje se brzo izmjenjuju, nije lišen konfuzije. Nadolaskom postmoderne započinje razgradnja gotovo svih sastavnica Parsonsovog koncepta ${ }^{28}$ i uloga bolesnika je dovedena u pitanje. ${ }^{29}$ Evidentno je da se u neoliberalnom ekonomskom sustavu, u postmoderni, zahtijeva sve veća osobna odgovornost i stavlja teret ozdravljenja na samog pacijenta, te se umjesto paternalizma ističu visoki zahtjevi za autonomijom, individualizmom, preuzimanjem odgovornosti i samokontrolom, koji inzistiraju da bolesnik, umjesto dosadašnje pasivne i krajnje podređene uloge, aktivno suodlučuje u svakoj fazi liječenja. ${ }^{30}$ Postmoderna bolest tako nastaje iz kulture koja preobražava naše iskustvo bolesti, opisane promjene paradigme i koncepta uloge bolesnika u društvu. Moć koja nas čini zdravima ili bolesnima ne počiva isključivo u mikroorganizmima i lijekovima već i u slikama i pričama. ${ }^{31}$

Ono što postmodernu bolest čini posebnom najbolje se može razumjeti ispitivanjem različitih posebnih slučajeva osobnih iskustava i ispričanih priča ili naracija u kojima se jasno prožimaju kultura i bolest. Taj je način prijelaz s isključivo biomedicinskog modela bolesti, za koji Morris tvrdi da je ograničen, na nov, nepotpun i neimenovan model, koji on naziva biokulturni model. ${ }^{32}$

Ideja izricanja i pričanja priča kao odgovornosti prema svjetskom, općeprihvaćenom zdravom razumu reflektira ono što se razumije kao ključno moralno pitanje i sam moral postmoderne. Pričanje je isto za druge kao i za sebe same. U recipročnom činu priče, narator daje sebe kao vodiča za autoformaciju drugih. Pričati priču u postmodernom vremenu, pokušaj je promjene vlastitoga života utječući na živote drugih, a priča, osobito priča o bolesti, tako postaje svjedočanstvo. ${ }^{33}$ Priča o bolesti pokušaj je pronalaženja onog glasa za iskustvo koje

\footnotetext{
${ }^{27}$ Usp. Moris, Bolest $i$ kultura ..., 41.

${ }^{28}$ Više o Parsonsovom konceptu uloge bolesnika u: Talcott PARSONS, The Social System, London, Routledge, 1991. i Peter BERGER, Thomas LUCKMANN, Socijalna konstrukcija zbilje, Zagreb, Naprijed, 1992, 195. Što je zapravo taj koncept? Parsonsov koncept uloge bolesnika (sick role) nosio je očekivanja da će bolesni ljudi ozdraviti i vratiti se svojim svakodnevnim obavezama u društvu. Biti bolestan značilo je poprimiti »socijalno doznačen identitet«. Parsons ne dvoji oko toga hoće li bolesna osoba pristati na terapeutski postupak i na taj način biti brže reintegrirana u društvo. Pravi izvor te motiviranosti Parsons nalazi u pacijentovoj vulnerabilnosti ili ranjivosti, te u bolesnikovoj motiviranosti za ostvarivanjem zadovoljstva organizma i samoočuvanja tijela. Ono što je bitno za Parsonsov koncept bolesti bila je neupitna vjera u ulogu i moć koju su liječnici imali u ozdravljenju bolesnika, te u samoj vjeri da je ozdravljenje moguće. Liječnikova je vlast nad bolesnikom bila dobrohotna i radi najboljeg interesa bolesnika. Oko tih uloga i onoga što su bolest i zdravlje nije bilo konfuzije.

${ }^{29}$ Usp. Ž. STANIČIĆ, Re(de)konstrukcija Parsonsovog koncepta uloge bolesnika u postmodernom društvu, Revija socijalne politike, 14 (2007) 3-4, 313-326, 319.

${ }^{30}$ Usp. isto, 320.

${ }^{31}$ Usp. Moris, Bolest i kultura..., 54.

${ }^{32}$ Usp. isto, 27; izraz potječe iz: L. G. MOORE i dr., The Biocultural Basis of Health. Expanding Views of Medical Anthropology, Long Grove, Waveland Press, 1986, 10-13.

${ }^{33}$ Usp. Frank, The Wounded Storyteller..., 18.
} 
medicina ne može opisati niti obuhvatiti. Narator nastoji ponovno zadobiti svoj život, jastvo, identitet i koherentnost života.

»Pričanje tako postaje refleksivan, terapeutski čin koji u sebi sadrži transformativan učinak za ljude koji su iskusili bolest. Priča, uključujući i moja osobna, proizlazi iz želje da se životu priskrbi koherentnost, integritet, punina i zaključak. «34

Ozbiljna i dugotrajna bolest utapa nas u neku drugu realnost, tuđu i stra$\mathrm{nu}, \mathrm{u}$ kojoj se gotovo sve mijenja. Ulazeći u zemlju bolesnih, postajući njezin stanovnik, državljanin s dvostrukim državljanstvom, naše stanje ne ovisi više samo o biološkim procesima već i o spolu, rasi, prihodima. ${ }^{35}$ Bolest je u tom slučaju slom priče, brodolom života, gubitak kontrole, cjelovitosti i smisla. Bolest smanjuje ili potpuno oduzima mogućnost slobode djelovanja i mijenja postojeće odnose i svijet bolesnika. Pričati priču znači zadobiti ponovno kontrolu nad životom uzdrmanim teškim iskustvom. Čin pričanja postaje time dvostruka afirmacija. Afirmacija jastva i identiteta onoga koji priča i onog drugoga koji sluša. ${ }^{36}$

Pripovjedač, kako ističe Arthur W. Frank, novi je lik postmodernog pacijenta. On više nije žrtva bolesti, niti puki predmet medicine, već osoba koja se bori za to da očuva i iznova artikulira onaj glas koji mu bolest često oduzima. Pripovjedač time sebi ponovno vraća pravo na sebe izlazeći izvan okvira moderne kulture i primata koji se dodjeljuju znanstvenoj medicinskoj priči. ${ }^{37}$

\section{Narativna medicina}

To nas dovodi i do paradigme narativne medicine. Kada spominjemo paradigmu i koncept narativne medicine moramo naglasiti da je on relativno novijeg datuma, iako su tendencije humaniziranja medicinske prakse oduvijek postojale i uvijek bile prisutne tijekom razvoja medicine i njezine prakse. Kao jedan od načina nošenja i odgovora na postojeću krizu skrbi u suvremenoj medicinskoj praksi, pojavljuju se nastojanja oko humaniziranja ili, bolje rečeno, rehumaniziranja modela pristupa pacijentu i njegovoj bolesti.

Narativna je medicina medicinski pristup koji se koristi i proizlazi iz osobnog narativa u kliničkoj praksi, istraživanjima i obrazovanju kao načinu promoviranja zdravlja i izlječenja. Model je to koji uvažava pacijenta kao osobu i njegovu osobnu priču kojom opisuje svoj osjećaj bolesti kao tegobe koja ga je zadesila, te uvažava i uzima u obzir njegove relacije, psihosocijalnu mrežu odnosa

\footnotetext{
${ }^{34}$ G. BECKER, Disrupted Lives. How People Create Meaning in a Chaotic World, Berkeley, University of California Press, 1997, 12.

${ }^{35}$ Usp. S. SONTAG, Illness as Metaphor, New York, Farrar, Straus and Giroux, 1978, 3.

${ }^{36}$ Usp. D. CARR, Time, Narrative, and History, Bloomington, Indiana University Press, 1986, 96.

${ }^{37}$ Usp. Frank, The Wounded Storyteller..., 70.
} 
kao i tjelesnu dimenziju bolesti koju osjeća. Taj nam model, često usporedan modelu koji se naziva i modelom objašnjavanja bolesti ili tzv. explanatory model of illness ${ }^{38}$ razotkriva na koje načine ljudi osmišljavaju svoju bolest i pruža nam relevantan okvir u kojem istraživači društvenih znanosti i zdravstveni djelatnici surađuju s pacijentima kao sudionicima sveobuhvatnog razumijevanja njihova živog iskustva bolesti. Medicinska praksa združena s narativnom kompetencijom tako postaje paradigmatski model humanije i efikasnije medicinske prakse.

Model objašnjavanja bolesti usko povezan s konceptom narativne medicine predložio je Arthur Kleinman s ciljem da se bolest i zdravlje smjeste unutar društveno-kulturološkog konteksta. Model istražuje različita osobna, intimna i subjektivna objašnjenja i iskustva bolesti, njihovu ulogu u društvu, društvenu realnost kao kulturološki oblikovanu i utjecaje osobnog iskustva na poimanje bolesti. Često ga on koristi za pokušaj objašnjenja onoga što i na koji način ljudi doživljavaju kada se suoče s bolešću, s njezinim uzrocima, tijekom i načinima kako utječe na ljudski život i identitet, s onim što im može pomoći da se osjećaju bolje. Metoda je to koja se koristi kako u kliničkom okruženju i kvalitativnim analizama, tako i kao način zadobivanja i prikupljanja individualnih, osobnih objašnjenja pojedinog fenomena bolesti i simptoma. ${ }^{39}$

Kleinman je oštro kritizirao mediocentrično viđenje i perspektivu bolesti, razlike između liječničkog viđenja i razumijevanja bolesti, te pacijentova iskustva tegoba. Da bi premostio jaz i pomogao kliničarima u nadilaženju mediocentričnog viđenja, predložio je osam pitanja kojima nastoji razlikovati između tegobe i bolesti, te premostiti jaz između kliničkog znanja i kulturnog konstrukta kliničke stvarnosti.

»Dozivajući pacijentovo osobno iskustvo i model objašnjenja liječnik zadobiva znanje o uvjerenjima koja pacijent ima o bolesti i tegobama, osobnim i društvenim značenjima koja pripisuje tegobama i poremećajima, njegovim očekivanjima o onome što će mu se dogoditi i što će liječnik učiniti, te njegovi vlastiti terapeutski ciljevi (...). To rasvjetljava konflikte, ne vezane uz različite stupnjeve znanja, nego drugačije vrijednosti i očekivanja. Jednom kada se učine očiglednim, dio kliničkog procesa uključuje u sebi pregovaranje između modela objašnjavanja bolesti i liječnikova tumačenja. « ${ }^{40}$

\footnotetext{
${ }^{38}$ Više o tom modelu objašnjavanja i tumačenja bolesti (eng. explanatory models of illness) u E. LYNCH, D. MEDIN, Explanatory models of illness. A study of within-culture variation, Cognitive Psychology, 53 (2006) 4, 285-309, 286; N. KAPLAN-MYRTH, Interpreting people as they interpret themselves. Narrative in medical anthropology and family medicine, Can Fam Physician, 53 (2007) 8, 1268-1269; J. HALLENBECK, The Explanatory Model, Journal of Palliative Medicine, 6 (2003) 6, 931-931; doi: https://doi.org/10.1089/109662 103322654820; D. B. MORRIS, Narrative Medicines. Challenge and Resistance, The Permanente Journal, 12 (2008) 1, 88-96; doi: https://doi.org/10.7812/tpp/07-088, A. KLEINMAN, Culture, Illness and Care. Clinical lessons from Anthropologic and Cross-cultural Research, Focus - the Journal of Lifelong Learning in Psychiatry, 4 (2006) 1, 140-149, 147; doi: https://doi.org/10.1176/foc.4.1.140.

${ }^{39}$ Usp. Rupčić, Bolest u procjepu biologije i kulture..., 436.

${ }^{40}$ Kleinman, Culture, Illness and Care..., 147.
} 
Narativna medicina uvažava i nastoji tretirati pacijente prateći njihovu priču o bolesti, a ne samo tjelesne simptome. Time ona uvažava ne samo osobno iskustvo pojedinog pacijenta, nego i ohrabruje kreativne potencijale i sposobnost imaginacije kao temeljne karakteristike moralnog pristupa, te u konačnici i empatiju i autorefleksiju samog liječnika.

Columbia University Medical Center, prominentna medicinska škola, 2000. godine je među prvima započela program narativne medicine, unutar studija za liječnike i kirurge. Kao pioniri vjerovali su da narativna medicina može pružiti duboke uvide i promjene u načinu shvaćanja i definiranja bolesti, u tretmanu bolesnika, te poboljšati narav skrbi u medicinskoj praksi. ${ }^{41}$ Rita Charon ističe:

»Narativna medicina počinje kao rigorozna intelektualna i klinička disciplina kako bi osnažila zdravstvenu skrb kapacitetima koji bi na stručan način mogli uzeti u obzir ona osobna razmatranja kako bi prepoznala, apsorbirala, interpretirala i bila potaknuta i dirnuta osobnim narativima drugih. « ${ }^{42}$

Njezine su metode opisane kao one koje povezuju i koriste kapacitete kreativnosti i dubokih uvida koji pomažu medicinskim profesionalcima ne samo da uspostavljaju dijagnozu i liječe pacijenta, nego da postanu dionikom i svjedokom njegovih osobnih patnji. Tako se povećava kapacitet i sposobnost liječnika da pojme i razumiju nevolje i patnju kroz koju prolaze pacijenti i pomognu im da izdrže kaos bolesti. Budući da priča o bolesti ima retrospektivan karakter i duboku moralnu poruku koja pomaže bolesnom subjektu da ponovno zadobije i rekonstruira svoj ranjeni identitet, $u$ konačnici i život narušen bolešću, praksa i metode narativne medicine upravo se koriste tim saznanjima da bi pomogle pacijentu u njegovim nastojanjima.

U bolesti ne biva samo tijelo narušeno, nego i psihološke i socijalne relacije. Bolest, koja je problem iz perspektive liječnika, svojom suženom biološkom terminologijom biomedicinskog modela, postaje alteracija u biološkoj strukturi ili funkciji. No, ono što je temeljna vrijednost i raspoloženje ovog tipa medicinske prakse je empatija koja oblikuje i mijenja stav liječnika prema pacijentu. Liječnik postaje svjesniji slikovitih ili eidetskih karakteristika pacijentove bolesti i njezinih metaforičkih značenja, uključujući njegov gubitak cjelovitosti, narušenu sigurnost, gubitak kontrole i slobode djelovanja kao indirektnih posljedica bolesti.

Kleinman ističe da klinička i bihevioralna znanstvena istraživanja nemaju kategorije kojima bi opisali ljudsku bol i patnju koju bolesnici osjećaju kao subjektivne i duboko osobne kategorije i dimenzije iskustva kojima opisuju svoje tegobe i bolesti. Medicinske su kategorije nedostatne da bi iskazale intimna nutarnja iskustva tegoba i bolesti. O patnji one su nijeme.

\footnotetext{
${ }^{41}$ Više o tom modelu vidi: Columbia University Medical Center, Program in Narrative Medicine; www.narrativemedicine.org.

${ }^{42}$ R. CHARON i dr., The Principles and Practice of Narrative Medicine, Oxford, Oxford University Press, 2016, Uvod.
} 
»Te metode onemogućavaju nas da obuhvatimo, iza jednostavnih zvukova tjelesne boli ili psihičkih simptoma, kompleksan nutarnji jezik povrede, očaja i moralne boli (i također trijumf) života s bolešću. «33

Potrebno je iznova reinterpretirati simptome bolesti kroz drugačiju, izmijenjenu interakciju liječnika i pacijenta. Irene Switankowsky identificira četiri prednosti dvostruke interakcije liječnik-pacijent. Prvi je da liječnik tretira pacijenta kao cjelovitu osobu, a ne samo kroz bolestan dio tijela. Bolest često utječe na sve dimenzije pacijentova života, a ne samo na neke dijelove njegova tijela ili neke aspekte njegova života. Bolest ga postavlja u egzistencijalnu krizu i pred životne izazove. Na taj način liječnik biva stavljen pred dvostruki izazov: pred pacijentovo živo iskustvo bolesti kroz koju prolazi i njegovo osobno viđenje simptoma. To nas dovodi, kako ističe Switankowsky, do druge prednosti »dualističkog interakcionizma «, ${ }^{44}$ a to je zabrinutost liječnika za pacijentovo osobno iskustvo bolesti i njegov narativ. Pacijentovo iskustvo bolesti ne dovodi u pitanje samo njegov fizički integritet nego zadire u njegov psihološki identitet i mijenja društvene relacije. Prema Switankowsky pacijentovo su tijelo i self (identitet) intrinzični aspekti bolesti i nerazdvojno su povezani, a tretman bolesti ne može biti uspješan bez tretmana cjelovite osobe. Treća prednost se nalazi u uključivanju objektivnih i subjektivnih dimenzija bolesti. ${ }^{45}$ Ona uključuje objektivno, znanstveno znanje nastalo prikupljanjem podataka u kliničkom istraživanju (desease) i pacijentovo subjektivno osobno iskustvo o onome što je bolest pacijentu (illness). ${ }^{46}$

Cassel odbija tzv. redukcionistički ili mehanicistički monizam koji stoji nasuprot dualističkom interakcionizmu, jer dijeli um, psihu od tijela po uzoru na Descartesov dualizam ili redukcionizam. ${ }^{47}$ On ističe dvojni karakter osobe koja je sastavljena i od tijela i uma, te je bliži i zagovara ontološki holizam i pristup pacijentu. Holizam je metafizička pozicija i pristup pacijentu koji ističe da cjelina ne može biti svodiva i reducirana na njezine pojedinačne dijelove niti njima

\footnotetext{
${ }^{43}$ A. KLEINMAN, The Illness Narratives. Suffering, Healing and the Human Condition, New York, Basic Books, 1988, 28-29.

${ }^{44}$ I. SWITANKOWSKY, Dualism and its Importance for Medicine, Theoretical Medicine and Bioethics 21 (2000) 6, 567-580, 577.

${ }^{45}$ Usp. isto, 567-580.

${ }^{46} \mathrm{O}$ razlikovanju dvaju termina illness (tegoba ili osobno pacijentovo viđenje i iskustvo bolesti) $\mathrm{i}$ desease (liječnikova interpretacija tegoba medicinskim terminima) vidi više u: Kleinman, The Illness Narratives..., 4-6; Moris, Bolest $i$ kultura..., 55; E. J. CASSELL, Illness and Disease, Hastings Center Report, 6 (1976) 2, 27-37; doi: https://doi.org/10.2307/3561497; B. S. TURNER, The Body \& Society, Nottingham, Nottingham Trent University, 2008, 174-177; Ch. BOORSE, On the Distinction Between Disease and Illness, Philosophy and Public Affairs, 5 (1975) 1, 4968; doi: https://doi.org/10.1515/9781400853564.3.

${ }^{47}$ Usp. M. WHEELER, God's Machines. Descartes on the Mechanization of Mind, u: P. HUSBANDS, O. HOLLAND, M. WHEELER (ur.), The Mechanical Mind in History, Cambridge, MIT Press, 2008, 307-330.
} 
biti protumačena, nego ti dijelovi proizlaze iz strukture cjeline. Osoba ne može biti reducirana na svoje dijelove da bi je se bolje razumjelo. ${ }^{48}$

Ontološki bi stoga holizam bio stav u kojem su entiteti kao što su pacijenti, osobe, stanice ili sl., sastavljeni od dijelova, ali ti dijelovi ga ne određuju niti definiraju nego čine bitan ali ne i jedini dio njihove cjelovitosti. Sve ovo smjera pomoći pacijentu da uvažavajući osobni narativ kroz priču o bolesti, ponovno rekonstruira životnu mapu i prihvati novi tijek života nastao tom bolešću. ${ }^{49}$

Frank u svojem djelu Reflection of Illness govori o tijelu koje ima svoju volju i sposobnost, te zagovara stav čuđenja i zadivljenosti nad tijelom i priznavanje njegove moći zadobivanja kontrole. ${ }^{50}$ Stav je to koji pomaže osobi koja je postala pacijent i ušla u svijet bolesnih, da zadobije svoje jastvo i svoj identitet natrag. Ono što nas bolest uči da, s onu stranu svega što mogu ili ne mogu više učiniti, tijelo naprosto jest i postoji ovdje i sada i ima svoju mudrost u kojoj imamo mogućnost zadobiti iznova sebe same. To čuđenje nad tijelom kroz priču o bolesti pomaže pacijentu obuhvatiti i shvatiti da je on utjelovljen, bilo da je zdrav ili bolestan. Reducirati tijelo na dijelove, osakatilo bi i priču i označilo gubitak integriteta životnog iskustva proživljenog kao utjelovljeni subjekt.

Priča nam kao i njezino razumijevanje pomaže dokučiti narav patnje i iskustva bolesti kao osobne, subjektivne tegobe i dubinu pacijentove patnje i svijeta. Prihvatiti pacijentov svijet, prema Casselu, znači pustiti i omogućiti pacijentu da ispriča liječniku svoju priču. Pacijent kao osoba tako nije smetnja u relaciji liječnik-pacijent, nego utemeljenje tog odnosa. Još je jedan važan izvor ulaska u pacijentov svijet i naraciju o boli i bolesti, a to je liječnikovo osobno razumijevanje ljudi, njihova jezika, ponašanja, emocija i vrijednosti, koje pružaju temelj za razumijevanje individue same. ${ }^{51}$

Cassel upućuje važno pitanje kada je u pitanju osoba i kvantifikacija podataka o bolesti na temelju njezine priče, a to je: Smije li pacijent biti mjeren $\mathrm{u}$ rasponima brojčanih vrijednosti i isključivo laboratorijskih nalaza i podataka. Objektivni podatci, iako temelj za medicinsku znanost, nedostatni su za kliničara. ${ }^{52}$ Prava mjera pacijenta kao osobe moraju biti i vrijednosti i osobna estetika ili estetsko iskustvo. Upravo one tvore pacijenta kao osobu. Value-free medicina je, unatoč svojoj atraktivnosti, kontradikcija u sebi. ${ }^{53}$ Vrijednosti su od presudne važnosti u medicini i praksi, a primjenjivati medicinsku znanosti i znanje na nekog pacijenta zahtijeva razmišljanje u terminima vrijednosti

\footnotetext{
${ }^{48}$ Usp. E. J. CASSEL, The Nature of Suffering and the Goals of Medicine, New York, Oxford University Press, 1991, 37.

${ }^{49}$ Usp. M. B. WOODHAUS, A Preface to Philosophy, Belmont, Wadsworth, 2000, 155.

${ }^{50}$ Usp. A. W. FRANK, At the Will of the Body. Reflections on Illness, Boston, Houghton Mifflin, 2002.

${ }^{51}$ Usp. Cassel, The Nature of Suffering and the Goals of Medicine..., 172.

${ }^{52}$ Usp. isto, 179.

${ }^{53}$ Usp. isto, 185.
} 
jednako kao i u terminima objektivnih činjenica o tijelu. ${ }^{54}$ Iako su pacijentove vrijednosti osobne i subjektivne, zaključuje Cassel, ne znači da ih liječnik ne treba uzeti u obzir i evaluirati na racionalan način donoseći dijagnozu i odluku o liječenju.

Osim vrijednosti, imamo još nešto što Cassel naziva osobna estetika ili osobno estetsko iskustvo, često subjektivno, utemeljeno na osjećajima, ali ne i bez značenja. Estetika je važna kada je u pitanju osoba i prosuđivanje osobe, jer je riječ o samostvarajućem i samoostvarujućem procesu koji ima kreativan potencijal jer je osoba uvijek osoba s potencijalom, s mogućnošću da to postane još više. Estetika naracije tako pruža podatke koji su važni i pomažu liječniku u vrednovanju istinitosti pacijentove priče i njezine potvrde kao vrijednog iskustva koje pruža uvide u uzroke i narav same bolesti i što ju je proizvelo, a samo pričanje tako zadobiva i terapeutsku dimenziju i pomaže u restauraciji slomljenog identiteta. »Postoji znanje o osobi koje može biti isključivo saslušano u terminima estetike, 'ispravnost i istinitost' pacijentove životne priče. $\aleph^{55} \mathrm{Bez}$ tog znanja, liječnik može doživjeti neuspjeh u poznavanju pacijenta i ublažavanju i olakšavanju njegove patnje. Jastvo na taj način proizlazi iz dijalektičkog procesa koji je i racionalan i fundamentalno etički jer priča sadrži i moralnu poruku.

U javnom prostoru, kao i u medicini koja postaje izrazito tehnificirana, sve je očitije da nedostaje sposobnost empatije, suosjećanja i skrbi. Sve je očitija ta kriza skrbi, jer se ona pokazuje kao nešto nebitno i kao nešto nadiđeno i neostvarivo u odnosu liječnik - pacijent. To odbijanje sućuti često je popraćeno i potaknuto pretjeranim oslanjanjem na tehnološke modele ljudskog ponašanja i odnosa, osobito onih koji proistječu iz ekonomskog utilitarizma. Time taj ugovorni model prevladava i unutar medicine same te se pretače na odnos liječnik - pacijent. Ti se modeli, iako vrijedni po sebi, pokazuju nedostatnima kao smjernice u živom odnosu.

Ono što nedostaje u prostoru javnog diskursa i odnosima koji ga sačinjavaju, upravo je priča i ono što priča nosi i pobuđuje, a to je snaga književne imaginacije. ${ }^{56}$ Pripovijedanje i književna imaginacija nisu u suprotnosti racionalnom diskursu i argumentaciji, nego im mogu poslužiti kao nadopuna i obogaćenje. Književna imaginacija pomaže u oživljavanju emocija sućuti i milosrđa, empatije i skrbi za drugoga. Ona nas uvodi u svijet drugoga i u način na koji netko drugi doživljava svoje iskustvo. Književna nam imaginacija pomaže da zamislimo kako se netko drugi osjeća u svojoj koži, te nam književna djela, ali i osobne priče ispričane osobnim jezikom, pomažu sagledati sve aspekte ljudskog iskustva.

\footnotetext{
${ }^{54}$ Usp. isto, 107.

${ }^{55}$ Isto, 202.

${ }^{56}$ Usp. M. NUSSBAUM, Pjesnička pravda. Književna imaginacija i javni život, Zagreb, Naklada Deltakont, 2005, 13.
} 
Sudac Oliver Wendell Holmes jednom je zapisao da izučavanje Aristotela može pokazati da »život ne zbraja brojke, nego slika sliku« ${ }^{57}$ Upravo je to onaj eidetski karakter priče koji je ovdje već spomenut. Odašiljanje ovih literarnih i egzistencijalnih sličica pokrenuto je željom i nastojanjima onoga koji priča da uspostavi i održi komunikaciju s drugima. Tako je svaka priča o bolesti niz slika nečijeg života koje se slažu poput puzzla ispisujući postupno okvir jedne životne priče. Slikanje i nizanje fragmenata priče, poput Demokritovskih eidola, ne zrcali samo tek jednu i neponovljivu egzistenciju, nego predstavlja pokušaj restauracije narušene i slomljene životne priče i pokušaj uspostavljanja komunikacije i narušenih relacija s izvanjskim svijetom.

Ono što se nameće kao potencijalan problem je neznanstvenost i subverzivnost naracije te književne imaginacije, za znanstvenu misao i medicinu utemeljenu na dokazima (evidence based medicine). No, ono što ističemo, kao i Nussbaum, upravo je duboka povezanost uobrazilje i imaginacije s etikom koja prožima u ovom slučaju, nama važan odnos liječnik - pacijent. Naime, priče kao i književna djela, potiču slušatelje na poistovjećivanje, suživljavanje, empatiju i sućut. One pozivaju i uznemiravaju, prizivaju snažne emocije, unose zbunjenost i nelagodu, te često zahtijevaju neugodno suočavanje s vlastitim stavovima, konvencijama, mislima i namjerama.$^{58} \mathrm{Na}$ taj način priča, bilo napisana ili ispričana, konstruira paradigmu stila etičkog razmišljanja do kojeg dolazimo ulazeći u prostor mašte i imaginacije, a to je uživljavanje i sućut. Upravo su imaginacija ili uobrazilja kao sposobnost uživljavanja i s njome usko povezana pozornost, koja je ustvari interes, kao djelatnosti uma, po sebi moralne značajke i moralno ključne sposobnosti bez koje su osiromašeni i osobni i društveni odnosi. ${ }^{59}$ Upravo takav pogled iznutra ili uobrazilja nije neutralna i ona potiče i njeguje širokogrudno tumačenje svijeta i drugih, što je važna razlika koja čini moralni život, te se u svjetlu toga može i shvatiti osobni narativ ispričan jezikom iskustva. ${ }^{60}$

U tom kontekstu, kada govorimo o bolesti koja prethodi liječnikovu razumijevanju i tumačenju, napominjemo da ona razara svijet bolesnika i ograničava njegovo tijelo. To tijelo povratno nameće ograničenja pacijentu koji je obolio. Bolest obuhvaća i temporalnu i spacijalnu dimenziju. Ona razara i naseljava prostorno-vremenski kontinuum pacijenta i temporalnu dimenziju, te razara i prostornu domenu pacijentovih relacija u kojima bolesno tijelo obitava. No, iako je bolest slom životne priče koja se uspostavlja kroz iznova ispričanu priču, ona pokazuje vrijednost narativa koji pomaže uspostavi tog kontinuuma, te cjeline, smisla i relacija na novim temeljima. Bolest izmješta pacijenta iz njegova svijeta da bi ga opet kroz priču vratila natrag. Liječnik u susretu s pacijentom

\footnotetext{
${ }^{57}$ O. W. HOLMES, Jr., Pismo Lewisu Einsteinu od 23. srpnja 1906., u: R. POSNER (ur.), Essential Holmes, Cambridge, Harvard Universitiy Press, 1991, 32.

${ }^{58}$ Usp. Nussbaum, Pjesnička pravda..., 26.

${ }^{59}$ Usp. isto, 61-63.

${ }^{60}$ Usp. isto, 66.
} 
i njegovom pričom o bolesti može jedino priznati da ne zna sve i da su uzroci bolesti tajanstveni i neuhvatljivi njegovu potpunom razumijevanju i shvaćanju, te ga navesti da prihvati tajnovitost njezine naravi. Upravo se u tome ogleda sva važnost narativa i same narativne medicine kao prakse koja uvažava taj osobni narativ.

\section{Zaključak}

Bolest nas smješta na samu marginu i rub života, time i egzistencije same. Boraviti u toj razdjelnici života stavlja i bolesnika i liječnika pred izazov. $\mathrm{Na}$ koji se način nositi s patnjom koju je prouzrokovala bolest? Upravo se razlika svjesnog i nesvjesnog života možda najjasnije očituje u stanju bolesti kada ona, razlika, čini jednu od bitnih razdjelnica što u ontološkom tkanju i silnicama života rasvjetljuju smisao boli i patnje. Upravo želeći istaknuti važnost osobne naracije i priče, posegnuli smo za objašnjenjima koja su snažno utjecala i na prevrat $\mathrm{u}$ suvremenom medicinskom shvaćanju i praksi, te donose izmjene $\mathrm{u}$ postojećem biomedicinskom modelu tumačenja bolesti. Ističući važnost naracije u medicini, istaknuli smo i nove tendencije koje nastoje uvesti vrijednost i važnost narativa bolesti, te se $u$ tom kontekstu sve više govori o tzv. narativnoj medicini.

Potrebno je još jednom istaknuti važnost koncepta narativne medicine koja ima tendenciju humaniziranja postojeće medicinske prakse u suvremenoj medicini, model je to koji uvažava pacijenta kao osobu i njegovu osobnu priču. Taj nam model, kao što je i istaknuto, razotkriva načine na koji ljudi osmišljavaju svoju patnju i pruža nam relevantan okvir unutar kojega je moguće postupati s osobnim borbama u iskustvu bolesti i patnje.

Najrelevantnije je moguće okruženje za ovaj model, kako ističe Kleinman, unutar primijenjene medicinske antropologije i kliničkog okruženja. On smatra da su kliničke društvene znanosti sposobne prevesti koncepte kulturne antropologije na klinički jezik radi praktične primjene, te implementirati taj pristup i na medicinsku praksu, ali i na medicinsko podučavanje da bi se strukturiralo osobno pacijentovo iskustvo bolesti i poboljšala kvaliteta skrbi. ${ }^{61}$

Kartezijski je dualizam prouzrokovao mnoge krive interpretacije i shvaćanja, te se smatra jednim od glavnih krivaca za mehanicističko-redukcionističko tretiranje bolesnika i shvaćanje njegove bolesti. Ono što je suvremenoj medicini danas prijeko potrebno jest stavljanje naglaska na spomenuti dvojni karakter bolesti i razvoj interakcije uma i tijela, što postaje esencijalno za dostojanstven tretman bolesnika. Praksa adekvatne skrbi vođena humanističkim principima u suvremenoj, visoko tehnološki opremljenoj medicini teška je i gotovo nemo-




guća bez usmjeravanja liječnika navedenim novim izvorima znanja koji proizlaze iz dualističkog modela bolesti. Ono za što se zalažemo da bi se medicina humanizirala i da bi se najbolje i na najcjelovitiji način moglo pomoći bolesniku kao cjelovitoj osobi, jest i uvažavanje osobnog narativa kao smjernice za takav dualistički interakcionizam između liječnika i pacijenta. Dakle, obraćati se isključivo biomedicinskom i znanstvenom znanju više nije dovoljno, ono što je potrebno njegova je nadopuna konceptom kulturne antropologije i znanjem koje iz njega proizlazi, a utemeljeno je u osobnom narativu, tzv. narativno znanje.

\author{
Darija Rupčić" \\ The Narrative Medicine \\ Reconstruction of Identity through Personal Narrative \\ Summary
}

The intention of this paper is to highlight and reflect on the development of one tradition that considers the importance of cultural influences on health and illness. Delicate balance between illness and culture is what constitutes the elusive truth of illness and post-modern understanding of the illness as biocultural phenomenon in biocultural model. By putting an emphasis on this narrative, we will critically overview the existing dominant biomedical model of illness and we will consider the possibility of introducing a new biocultural model of illness expanding the existing biomedical model. In that context the narrative medicine has evolved, assuming that mere scientific knowledge and clinical medical practice are insufficient in the circumstances of the patient's personal struggle with the illness, and thus recognizes, absorbs and reinterprets his experience. The expected scientific contribution of this work will go towards the possibilities of theoretical and practical foundation and a search for the possibility of the different pluriperspective approach to illness and health.

Key words: illness, health, biocultural and biopsychosocial model, narrative medicine, metaphors of illness, narrative identity, explanatory model of illness.

(na engl. prev. Darija Rupčić)

\footnotetext{
* Darija Rupčić, PhD, Postdoctoral research fellow, Faculty of Humanities and Social Sciences, University of J. J. Strossmayer Osijek; Address: L. Jägera 9, HR-31000 Osijek, Croatia; E-mail: darijarupcic@gmail.com.
} 